University of South Florida

DIGITAL COMMONS

Digital Commons @ University of

@ UNIVERSITY OF SOUTH FLORIDA

South Florida

Educational and Psychological Studies Faculty

Publications

Educational and Psychological Studies

8-2007

\title{
African Americans and the Struggle for Opportunity in Florida Public Higher Education, 1947-1977
}

\author{
Larry Johnson \\ University of South Florida, ljohnson@htpt.usf.edu \\ Deirdre Cobb-Roberts \\ University of South Florida, cobbrob@usf.edu \\ Barbara Shircliffe \\ University of South Florida
}

Follow this and additional works at: https://digitalcommons.usf.edu/esf_facpub

Part of the Social and Philosophical Foundations of Education Commons

\begin{abstract}
Scholar Commons Citation
Johnson, Larry; Cobb-Roberts, Deirdre; and Shircliffe, Barbara, "African Americans and the Struggle for Opportunity in Florida Public Higher Education, 1947-1977" (2007). Educational and Psychological Studies Faculty Publications. 4.

https://digitalcommons.usf.edu/esf_facpub/4
\end{abstract}

This Article is brought to you for free and open access by the Educational and Psychological Studies at Digital Commons @ University of South Florida. It has been accepted for inclusion in Educational and Psychological Studies Faculty Publications by an authorized administrator of Digital Commons @ University of South Florida. For more information, please contact digitalcommons@usf.edu. 


\title{
African Americans and the Struggle for Opportunity in Florida Public Higher Education, 1947-1977
}

\author{
Larry Fohnson \\ Deirdre Cobb-Roberts \\ Barbara Shircliffe
}

In the decades following World War II, access to higher education became an important vehicle for expanding opportunity in the United States. The African American-led Civil Rights Movement challenged discrimination in higher education at a time when state and federal government leaders saw strengthening public higher education as necessary for future economic growth and development. Nationally, the 1947 President's Commission on Higher Education report Higher Education for American Democracy advocated dismantling racial, geographic, and economic barriers to college by radically expanding public higher education, to be accomplished in large part through the development of community colleges. Although these goals were widely embraced across the country, in the South, white leaders rejected the idea that racial segregation stood in the way of progress. During the decades following World War II, white southern educational and political leaders resisted attempts by civil rights organizations to include desegregation as part of the expansion of public higher education. ${ }^{1}$

Larry Johnson is an Assistant Professor at the University of South Florida, St. Petersburg (email: ljohnson@htpt.usf.edu). Deirdre Cobb-Roberts and Barbara Shircliffe are Associate Professors at the University of South Florida, Tampa. Dr. Johnson's work on this project was supported in full or in part by a grant from the University of South Florida St. Petersburg New Investigator Research Grant Fund or Senior Investigator Research Grant Fund. This support does not necessarily imply endorsement by the univeristy of research conclusions. The authors gratefully acknowledge the editorial suggestions from Sherman Dorn, Linda Perkins, and Julie Rueben; their insights were invaluable. We would also like to acknowledge the work of Mr. Richard Friend, Dr. Johnson's extraordinary undergraduate research assistant. Richard was killed in a tragic motorcycle accident. Our heart-felt condolences go out to his family and friends.

${ }^{1}$ United States, President's Commission on Higher Education, Higher Education for American Democracy, 6 vols. (Washington, DC: Government Publishing Office, 19471948); John Thelin, A History of American Higher Education (Baltimore: Johns Hopkins University Press, 2004); Steven Brint and Jerome Karabel, The Diverted Dream: Community Colleges and the Promise of Educational Opportunity in America, 1900-1985 (New York: Oxford University Press, 1989); Glenn Feldman, ed., Before Brown: Civil Rights and White Backlash in the Modern South (Tuscaloosa: University of Alabama Press, 2004). 
The history of public higher education for African Americans in Florida provides an excellent opportunity to examine these institutional and political dynamics. Following World War II, Florida public higher education expanded dramatically, while at the same time, state leaders maintained racial segregation well after Brown v. Board of Education (1954) declared it to be unconstitutional. Hawkins v. Board of Control (1954), the first attempt to apply Brown to higher education, became a notorious example of southern defiance. Florida's Board of Control, which oversaw the system of higher education, governors, the State Supreme Court, legislators, and other state and local officials engaged in a variety of strategies to continue segregation. In addition to ongoing litigation to block and delay desegregation, state officials expanded segregated public higher education through the creation of a racially separate junior college system. In the 1950s and early 1960s, Florida officials offered enlarged, but still not equal, educational opportunities for African Americans as an alternative to desegregation. Following the passage of the Civil Rights Act of 1964, these officials responded to increased pressure to desegregate public higher education by intensifying threats to dismantle black institutions, implying that African Americans would lose existing institutions that were educating large numbers of black students if they continued to press for integration. Whites precipitously closed the black junior colleges and the only public law school blacks could attend. Civil rights leaders and African American educators, in turn, argued that redressing past discrimination and offering educational opportunity to African Americans required the states both to strengthen historically black institutions and to desegregate historically white ones. In this article, we argue that by creating a false choice between black institutions and integration, Florida officials effectively continued their historic resistance to equitable access and opportunities for African American students in the state's colleges and universities. ${ }^{2}$

\section{The Development of Florida Public Higher Education before Brown}

When Brown was handed down, there were three public universities in Florida's dual system of higher education: the University of Florida (UF) in Gainesville and Florida State University (FSU) in Tallahassee for whites only, and Florida Agricultural and Mechanical University (FAMU) also in Tallahassee, for blacks. Both white universities trace their origins to legislation passed in 1851 establishing two seminaries of

\footnotetext{
${ }^{2}$ Joseph A. Tomberlin, "Florida and the Desegregation Issue, 1954-1959: A Summary Overview," The Fournal of Negro Education 43 (1974): 457-467.
} 
higher learning, one east of the Suwannee River and the other west of the river in the panhandle. The Seminary West of the Suwannee River, located in Tallahassee, provided pre-collegiate training for white men and women, but its limited collegiate courses were for men only. East Florida Seminary originally opened in Ocala but was closed during the Civil War; when it reopened in 1866, it moved to Gainesville.

Several public colleges for whites opened in Florida before the turn of the twentieth century, primarily serving economically and socially privileged students. The 1884 opening of Florida Agricultural College in Lake City as a land grant college extended higher education opportunities to a broader range of Florida's white population. The Morrill Act of 1862 that created land grant colleges in the United States was the first concerted effort by the federal government to expand higher education, a function previously left to the states. Its purpose was to "promote the liberal and practical education of the industrial classes on the several pursuits and professions in life." Each state was allotted 30,000 acres of public land for each senator and representative. Proceeds from the sale of the land were to be used to endow at least one college that would offer training in agricultural and mechanical arts. ${ }^{3}$ Supporters of the land grant colleges viewed their curriculum focused on agriculture, engineering, mechanics, and mining - compressed into the familiar "A \& M" acronym - as a challenge to the intellectual elitism as well as the "esoteric" subjects of the Ivy League. ${ }^{4}$ After the turn of the century, Florida Agricultural College would be combined with the seminary in Gainesville and two other institutions to create the University of Florida.

Higher education for blacks developed slowly in the South. During the antebellum period, Florida like other southern states made no provision for the education of blacks at any level. Two Florida counties allowed blacks to attend school legally, but only in private elementary schools. ${ }^{5}$ In the North, by contrast, blacks enjoyed greater access to education, and Cheney, Lincoln, and Wilberforce colleges had been established before the Civil War. Florida did not open a public college for blacks until 1887 when the State Normal School for Colored Students opened in Tallahassee. The curriculum provided instruction in elementary and secondary subjects - like that in many early black and

${ }^{3}$ Act of July 2, 1862, ch. 130, 12 Stat. 503,7 U.S.C.301 et seq., available on the Higher Education Resource Hub at http://www.higher-ed.org/index.html, hereafter HERH. The curriculum also included training in "military tactics."

${ }^{4} J o h n$ Thelin, "Higher Education and the Public Trough: A Historical Perspective," in Public Funding and Higher Education: Changing Context and New Rationales, eds. Edward P. St. John and Michael D. Parsons (Baltimore, MD: John Hopkins University Press, 2004), 27.

${ }^{5}$ Gil Wilson, "Education of Blacks Here Dates Back to 1850," St. Augustine Record, 6 October 2004, http://www.staugustine.com/stories/020802/com_468362.shtml 
indeed white colleges - and focused on preparing African American teachers. The Second Morrill Act, passed in 1890, provided states land to endow colleges serving African Americans; the next year Florida's black normal school was designated a land grant institution, becoming one of seventeen black land grant colleges in the South. ${ }^{6}$ As originally conceived, the act was intended to promote equality. It forbade paying for colleges "where a distinction of race or color is made in the admission of students." However, to secure passage sponsors had to compromise with segregationists. Consequently, the final legislation included language that allowed funding for segregated colleges: "the establishment and maintenance of such colleges separately for white and colored students shall be held to be in compliance with the provisions of this act if the funds ... be equitably divided." "As a result, this legislation extended educational opportunities to African Americans while allowing states to deny them access to white colleges and universities. Thus, southern and border states were able to use federal support in building their segregated systems of higher education. Under these circumstances, the land grant money was crucial in sustaining Florida's black normal school. After receiving land grant status, the normal school changed its name to the State Normal and Industrial College for Colored Students.

By 1905, Florida had six colleges for whites and one for blacks. A seventh white school had been authorized by the legislature, but Governor Napoleon Bonaparte Broward led an effort to reduce the number of colleges and create a centralized agency, the Florida Board of Control, which would govern the state's higher education system. The Buckman Act consolidated the six white schools into two. East Florida Seminary, St. Petersburg Normal and Industrial School, the South Florida Military College in Bartow, and the Florida Agricultural College were consolidated to create the University of the State of Florida in Gainesville. This new university was open to white men only and would soon shorten its name to the University of Florida. Florida State College was designated a women's university and its name changed to Florida State College for Women. Its name was changed to Florida State University in 1947 when it became coeducational again. The Buckman Act designated the Normal School for Colored Students a postsecondary institution, which opened opportunities for blacks to study college level subjects. Five years later the college awarded its first baccalaureate degrees and changed its name to Florida Agricultural and

\footnotetext{
${ }^{6}$ John W. Davis, "The Negro Land-Grant College," The fournal of Negro Education 2 (1933): 316, 31-328.

${ }^{7}$ Morrill Act of 1890 , ch. 841, 26 Stat. 417, 7 U.S.C. 322 et seq., available at HERH. See also, Jean L. Preer, Lawyers v. Educators: Black Colleges and Desegregation in Public Higher Education (Westport, CT: Greenwood Press, 1982), 8.
} 
Mechanical College for Negroes (FAMC), which remained the only public college for African American men and women in Florida. ${ }^{8}$

State funding for the three universities was unequal during the first decades of the twentieth century. While the white women's college initially received state funding equal to what the men's university received from its land grant endowment and the state, over time the state increased the men's funding much more rapidly than the women's. The state continually shortchanged FAMC throughout the period before Brown. Although FAMC received the same amount of funding under the land grant program as the UF, it received far less state money. In 1920, both received $\$ 25,000$ under the Morrill Act, but UF received $\$ 146,000$ from the state while FAMC received only $\$ 25,937$. By the end of the Second World War in 1945, both still received $\$ 25,000$ in land grant money, but UF's state appropriation had risen to $\$ 1,035,000$ while FAMC's was only $\$ 201,097$. The meager state funding forced FAMC to raise funds from private sources to meet regular operating costs. In fact, one former president described the institution as a "state-assisted" rather than a "state supported" college due to its heavy reliance on funds from philanthropic organizations and the federal government. ${ }^{9}$ FAMC faculty and administrator salaries were only a fraction of those at UF. For example, in 1922, UF paid English professors \$2,700 while FAMC paid them only $\$ 800$. The UF president received $\$ 5,000$, more than twice the $\$ 2,250$ paid to the FAMC president. ${ }^{10}$ FAMC was not allowed to develop graduate and professional programs until midcentury. Then, it only received a law school under the pressure of Virgil Hawkins's lawsuit. Facing the demand to desegregate UF, the state elevated FAMC to university status in 1953 and changed the name to Florida Agricultural and Mechanical University (FAMU). While the new university received some graduate and professional programs, they were never as extensive as those offered in the whites-only universities.

${ }^{8}$ Larry Johnson and Borman, Kathryn, "Competing Ideals of University Governance: Placing the Conflict between Jeb Bush and Bob Graham in Historical Context," in Education Reform in Florida: Diversity and Equity in Public Policy, ed. Kathryn Borman and Sherman Dorn (Albany: State University of New York Press, 2007). See also, Jno and Tigert, "Co-ordination in Florida," Fournal of Higher Education 4 (1933): 138141. There were several private colleges serving both whites and African Americans in Florida at the time of the consolidation. Florida Agricultural College had changed its name to the University of Florida just before consolidation. That name was quickly appropriated by the new university.

${ }^{9}$ B.L. Jr. Perry, "Black Colleges and University in Florida: Past, Present and Future," Fournal of Black Studies 6 (1975): 74.

${ }^{10}$ Florida Board of Control, Report of the Board of Control (Tallahassee). Data are from the reports for 1920,1933, 1935, 1945. For a discussion of unequal state funding of black colleges see Albert L. Samuels, Is Separate Unequal? Black Colleges and the Challenge to Desegregation (Lawrence: University of Kansas Press, 2004), 37. 
Thus, when the U.S. Supreme Court handed down the Brown decisions in 1954 and 1955, Florida's dual higher education system was firmly in place. No African American had been allowed to enroll in either undergraduate or graduate programs at UF or FSU. In contrast, offering limited programs and chronically underfunded, FAMU was separate and strikingly unequal to the white schools. Blacks had been challenging these inequities and fighting to expand their educational opportunities for a number of years. The next section will examine their challenges to Florida's dual system before Brown.

\section{Challenging Segregated Public Higher Education in Florida Before Brown}

In April 1949, thirty-nine-year-old Virgil Hawkins, a graduate of Edward Waters College and Bethune-Cookman College, two historically black, private colleges, applied for admission to the University of Florida School of Law. He was one of five African Americans to apply for admission to UF graduate programs that spring. All five went to court after being denied admission. The others soon dropped their cases, but Hawkins fought for nine years to be admitted. The state responded to his challenge by authorizing a law program at FAMC and eventually opening the door for African Americans to obtain graduate and professional degrees at Florida's white public universities, although Hawkins himself would never be admitted. ${ }^{11}$

Hawkins had wanted to be a lawyer since childhood, when he had seen a court in his small town give lengthy sentences to a group of black men who could not afford lawyers. His family had suffered white brutality; an uncle had been murdered after an argument with a white neighbor, and another uncle had been forced to watch as his son was lynched. ${ }^{12}$ When he applied for law school, he wanted to do something to improve the lives of African Americans, and like many faculty and other students at Bethune-Cookman, he felt the time was right-World War II would bring about positive opportunities for change. ${ }^{13}$ Indeed, historians consider the decade following World War II a watershed for

\footnotetext{
${ }^{11}$ Some useful articles on the Hawkins case are Darryl Paulson and Paul Hawkes, "Desegregating the University of Florida Law School: Virgil Hawkins v. The Florida Board of Control," 12 Florida State University Law Review 59 (1984); Lawrence A. Dubin, "Virgil Hawkins: A One-Man Civil Rights Movement," 51 Florida Law Review 913 (1999) http:// web.lexis-nexis.com/universe/document?_m=047cb73c7581765bf26d240fda078d40\&_ docnum=3\&wchp=dGLbVtz-zSkVb\&_md5=8399d0cf9088ea9a5e1dc2a8df797138.

${ }^{12}$ Lawrence A. Dubin, "One-Man Civil Rights Movement," $914 \mathrm{f.}$

${ }^{13}$ Interview with Harley S. Herman, Hawkins's historian and attorney, in Leesburg, Fla. (4 August 1992) (on file with the Florida Law Review); cited in Dubin, p. 916.
} 
civil rights activism. The emerging social, political, and economic climate after the war gave energy to the civil rights movement and inspired hope of reaching its goal of dismantling the most visible symbol of American racism: Jim Crow.

During the war, many African American leaders advocated victory abroad and victory at home, connecting America's war against fascism to the domestic civil rights struggle. African Americans who had served overseas returned home having experienced life free of many of the constraints imposed on them in the South. After the war, the oppression of blacks, captured in Gunnar Myrdral's widely read An American Dilemma, became a national and international embarrassment for the United States and policy makers in Washington increasingly came to believe that ending de jure segregation would advance U.S. interests in the cold war. As legal historian Mary Dudziak notes in her analysis of the connection between cold war and civil rights politics: "The thinking that World War II was a war against racial and religious intolerance, and that the United States stood to gain from promoting equality at home was so widespread that Frank Sinatra even sang about it." 14 The postwar economic boom raised expectations of social and economic mobility among Americans, but particularly among African Americans, who found increasing support for the movement against racism among white liberals.

A series of blows, some struck by the Truman administration, some by National Association for the Advancement of Colored People litigation, and others by grassroots activism, weakened segregation during the postwar period to give people like Hawkins hope. ${ }^{13}$ Two commissions appointed by President Harry Truman powerfully opposed Jim Crow. Responding to instances in which African American men and women had been "killed, maimed, or intimidated," some of whom were returning veterans who had fought overseas, Truman appointed a President's Commission on Civil Rights. In October 1947, its report To Secure These Rights declared "separate but equal" to be "one of the outstanding myths of American history for it is almost always true that while indeed separate, these facilities [to provide educational, recreational and other public services] are far from equal." The Commission recommended "the elimination of segregation, based on race, color, creed, or national origin, from American life." 16 Truman

\footnotetext{
${ }^{14}$ Mary Dudziak, Cold War/Civil Rights: Race and the Image of American Democracy (Princeton, NJ: Princeton University Press, 2000), 9.

${ }^{15}$ Raymond Arsenault, "You Don't Have to Ride Jim Crow': CORE and the 1947 Journey of Reconciliation," in Feldman, Before Brown, 21-67.

${ }^{16}$ President's Commission on Civil Rights, To Secure These Rights: The Report of the President's Committee on Civil Rights. The first quote is from Truman's Executive Order on
} 
also appointed a commission to address the lack of access to higher education faced by large segments of the U.S. population. Although the GI Bill had dramatically expanded access for veterans, people in rural areas or growing city centers, racial minorities, women, and those who were not veterans still had limited opportunities. Believing that confining higher education to an elite would undermine democracy, seeing an important role for higher education in national security, individual development, and social mobility, Truman appointed a commission to lay out a blueprint for the expansion of U.S. higher education. This commission's 1947 report, Higher Education for American Democracy, also denounced segregation. John Thelin described this report as a turning point in the federal government's role in expanding access to higher education by advocating the removal of geographic, racial and financial barriers to a college education. ${ }^{17}$ Southerners wrote dissents in both reports arguing that any desegregation should come about slowly and the federal government should not interfere in state control of education. In 1948, Truman issued an executive order desegregating the armed forces, an act that bolstered blacks' hopes for dismantling Jim Crow. ${ }^{18}$

In this political climate the National Association for the Advancement of Colored People's Legal Defense and Education Fund (LDF) achieved critical legal victories based on a strategy of proving in court that segregation was unconstitutional. ${ }^{19}$ This strategy traces back

December 5, 1946, vii, 81, 166, http://www.trumanlibrary.org/civilrights/srights1. See also, Richard M. Dalfiume, Desegregation of the U.S. Armed Forces: Fighting on Two Fronts: 1939-1953 (Columbia: University of Missouri Press, 1969), 137.

${ }^{17}$ John Thelin, A History of American Higher Education (Baltimore: Johns Hopkins University Press, 2004).

18 During the postwar years, the U.S. Supreme Court also ruled against segregated schools for Mexican American children in Mendez v. School District of Orange County (1946) and Delgado v. Bastrop (1948).

${ }^{19}$ For works on the history of NAACP's litigation campaign, see Mark Tushnet, The NAACP's Legal Strategy against Segregated Education, 1925-1950 (Chapel Hill: University of North Carolina Press, 1987). Tushnet argues that the Legal Defense Fund adjusted its strategy (shifting from equalization to challenging segregation) based on organization needs. However, Robert Carter strongly disputes Tushnet's interpretation, claiming the organization's legal strategy "followed a cohesive, unitary course from Margold to Marshall" with the goal of legal victory declaring segregation unconstitutional and by so doing may have cost the organization support. See Robert Carter, "Review: The NAACP's Legal Strategy against Segregated Education," Michigan Law Review 86, no. 6 (May 1998): 1083-1099. Other books detailing the history of the NAACP campaign against segregated schools include, Richard Kluger, Simple fustice: The History of Brown v. Board of Education and Black America's Struggle for Equality (New York: Random House, 1977); Constance Motley, Equal Fustice Under the Law (New York: Farrar, Straus and Giroux, 1998);James Patterson, Brown v. Board of Education: A Civil Rights Milestone and Its Troubled Legacy (Oxford: Oxford University Press, 2001); Jack Greenberg, Crusaders in the Courts: How a Dedicated Band of Lawyers Fought for the Civil Rights Revolution (New York: Basic Books, 1994); Robert Rabins, Lawyers for Social Change: Perspectives on Public Interest 
to Nathan Margold, hired by the NAACP in 1933 to develop a line of attack against segregation. Margold rejected any legal plan to demand equal public education facilities (as mandated by Plessy) because "few districts would be equalized, soon they would slip back into inequality, and the struggle would have to start all over again." ${ }^{20}$ Instead Margold argued for a direct challenge to segregation by using a concept from an 1886 case, Yick Wov. Hopkins. In this case, the Supreme Court ruled a San Francisco ordinance "banning laundries in wooden buildings" discriminated against Chinese laundries. ${ }^{21}$ The Courts had never been asked if segregation as practiced violated the constitution, and Margold thought that the courts might rule that it did. LDF chief counsel Jack Greenberg later summarized Margold's argument: "The idea was that if wherever there was segregation there also was inequality, which was invariably the case, segregation, therefore, was, unconstitutional."22

During the 1930s, NAACP lawyers strategically focused their challenge to state mandated segregation on graduate and professional schools because this was where the "white citadel of school segregation" was "most vulnerable." ${ }^{23}$ Their argument was that denying African Americans access to graduate and professional programs in white schools meant denying access to a specific training such as pharmacy and law unavailable at Historically Black Colleges and Universities (HBCUs). NAACP attorney Thurgood Marshall wanted to establish a record that unequivocally demonstrated that inequality resulted from school segregation.

In the postwar years, the LDF led by Marshall secured several important victories that should have paved the way for a positive result in the Hawkins case. The courts struck down state proposed alternatives to desegregation, including out of state scholarships, plans to improve upon or build new historically black colleges, and racially designated seating, study tables, and residential facilities within historically white colleges. Those decisions stipulated several higher-education obligations of states: a state must offer schooling for African Americans as soon as it is provided for whites (Sipuel v. Board of Regents of University of Oklahoma, 1948); black students must receive the same treatment as white students (MacLaurin v. Oklahoma State Regents, 1950); and a state must provide facilities of comparable quality (Sweatt v. Painter, 1950). As a result of these cases, the U.S. Supreme

Law (New York: American Bar Foundation, 1976). Preer discusses the irony and problem with basing the argument against segregation on the inferiority of Black schools.

${ }^{20}$ Jack Greenberg, Crusaders in the Courts, 58.

${ }^{21}$ Ibid., 56.

${ }^{22}$ Ibid., 59.

${ }^{23}$ Kluger, Simple fustice, 155. 
court clarified that it was the states' responsibility to provide qualified citizens with access to higher education programs within its own borders and that inequalities existed among colleges and universities with respect to the quality and the status of their programs.

Both before and after the Hawkins case was filed, legal challenges integrated universities in a number of states. The LDF secured victories at several universities, including Maryland (1936), Missouri (1938), West Virginia (1938), Arkansas (1948), Delaware (1948), Oklahoma (1948), Kentucky (1949), Louisiana (1950), Texas (1950), Virginia (1950), and would soon secure victories in North Carolina (1951) and Tennessee (1952) shortly after the filing. As the first desegregation case filed in Florida, Hawkins's suit represented an important challenge in the Deep South, and a victory in the case would have had far-reaching consequences. As the statewide higher education governing body, the Board of Control flatly denied their applications for admission to UF but offered them scholarships to attend school out of state. After Hawkins rejected the offer, and the Board of Control realized the case might go to trial, the board ordered the establishment of a law division at FAMC. The Board and Attorney General Richard Ervin formulated a strategy of adding postgraduate programs at FAMC, such as the new Law School, in the hope that expanding educational opportunities for African Americans would undermine the legal campaign against segregation.

After finding that Hawkins met "all the scholastic, moral and other qualifications except as to race and color" for admission, the Florida Supreme Court ignored recent precedents set by the U.S. Supreme Court and denied Hawkins's petition. Contrary to the U.S. Supreme Court's reasoning in Gaines v. Canada, the Florida Court's 1950 decision accepted the Board of Control's plan to establish a law school at FAMC as satisfying the equal protection clause of the fourteenth amendment. ${ }^{24}$ However, the court did state that until the facilities and operation of the new law school had been established, Hawkins "could be given instruction temporarily at the state institution of higher learning for white students." 25 Despite this ruling, the Board of Control refused to admit Hawkins even temporarily. Hawkins again petitioned the court to force the university to admit him. The Florida Supreme Court ruled that Hawkins failed to re-apply to UF and brought no evidence that the state was not providing a comparable education at the black college. After reapplying and putting forth arguments that the new Law School at FAMC was an "organization on paper," Hawkins

\footnotetext{
${ }^{24}$ State ex rel. Hawkins v Board of Control of Florida et al., 47 So. 2d 608, 609, 708; 1950 Fla. Lexis 1052.

${ }^{25} \mathrm{Ibid}$.
} 
tried again. ${ }^{26}$ However, the Florida Supreme Court ruled that the Board of Control had fulfilled its constitutional duty by creating a law school at FAMC ${ }^{27}$ Hawkins and LDF attorney Robert Carter then requested that the United States Supreme Court review the decision.

A week following their decision in Brown, the U.S. Supreme Court vacated the Florida's Supreme Court's ruling in Hawkins, remanding the case back "for consideration in light of the Segregation Cases decided May 17, 1954, Brown v. Board of Education ... that now prevail." 28 This ruling that Brown applied to higher education should have led to quick victory for Hawkins. LDF attorney Constance Motley took over Hawkins's case. In her book Equal fustice under the Law, the civil-rights attorney who was later a federal judge recalls appearing before "a group of stone-faced white male justices" in what she describes as "our (LDF) first brush with massive resistance." ${ }^{29}$ She had in mind not the violent terrorism, the shooting, beatings, and cross burnings of the radical right but the coordinated efforts of officials at all levels of state government to resist even token desegregation. Florida officials continued to resist Hawkins's admission to UF, unabashedly circumventing U.S. Supreme Court rulings that he be admitted. Eventually, as we discuss later, Hawkins agreed to withdraw his application in exchange for UF being opened up to other African American students.

Brown did not end discrimination against African Americans in higher education admissions to colleges and universities established for whites, despite the U.S. Supreme Court ruling that Brown prevailed in higher education as well as public schools. Instead, Hawkins demonstrated the limits of Brown as the Florida State Court and Board of Control continued to refuse admission of African Americans to the UF for four years after the landmark decision. The resistance to even token desegregation in Florida paralleled actions in other states in the Deep South. African Americans did not attend historically white institutions in Georgia until 1961, in Mississippi until 1962, Alabama and South Carolina until 1963, although Aurtherine Lucy briefly attended the University of Alabama in 1956 before being expelled. As explained by Peter Wallenstein, higher education desegregation was an uneven process. All southern states resisted it; and some such as Florida were more stubborn than others, refusing to admit an African American

${ }^{26}$ Algia Copper, "Brown v. Board of Education and Virgil Darnell Hawkins Twenty-Eight Years and Six Petitions to Justice," The Fournal of Negro History 64 (1979): $1-20$.

${ }^{27}$ Joseph A. Tomberlin, "The Negro and Florida's System of Education: The Aftermath of the Brown Case" (Florida Sate University, Ph.D. Dissertation, 1967), 154. ${ }^{28}$ Hawkins et al. v. Board of Control of Florida et al., 347 U.S. $971 ; 74$ S. Ct. $783 ; 98$ L.

Ed. 1112; 1954 U.S. LEXIS 2047; Motley, Equal fustice, 112, 113.

${ }^{29}$ Ibid., 113. 
until 1958. ${ }^{30}$ In Florida, Maryland, Arkansas, and Tennessee, Wallenstein notes that the enrollment of "black students in graduate and professional programs predated undergraduates by at least four years." ${ }^{31}$ Yet, violent white protests did not surround higher education desegregation as it did the desegregation of public elementary and high schools, a public peace suggesting the "drama was of a far more subtle sort." ${ }^{32}$ The next section explores the subtle and not so subtle ways Florida's political and educational leaders attempted to divert the desegregation of higher education.

\section{Florida's Response to Brown: Resistance and Expansion of Segregated Public Higher Education}

When Brown was handed down in 1954, Florida had yet to admit a single African American to a white university. This was the result of a determined effort by governors, the Board of Control, legislators, and judges to preserve segregation. The year before, while Brown was pending before the U.S. Supreme Court, the Board of Control acted on the belief that it might be vulnerable to further litigation like Hawkins's under the "separate but equal" doctrine. The board designated FAMC a university, changed its name to Florida Agricultural and Mechanical University (FAMU), and authorized a pharmacy program. Once the court rendered its decision, white politicians and government officials adopted a complex strategy of

\footnotetext{
${ }^{30}$ Tomberlin, "Florida and the Desegregation Issue," 457-467.

${ }^{31}$ Peter Wallenstein, "Black Southerners and Non-Black Universities: Desegregating Higher Education 1935-1967," History of Higher Education Annual 19 (1999): 121-148, 142. Wallenstein provides a critical look at desegregation in higher education to suggest directions for future historical research. Wallenstein concludes in the seventeen states desegregation was initially prompted by court order at one institution before the state adopted "less exclusive racial policy at other schools" (127). For a recent history of desegregation of higher education in Texas, see Amilcar Shabazz, Advancing Democracy: African Americans and the Struggle for Access and Equity in Higher Education in Texas (Chapel Hill: University of North Carolina Press, 2004). Shabazz argued that advocates of "liberal integrationism" (borrowing a term from Manning Marable) overcame the "legal barriers" to access to higher education. Commenting on the limited history of desegregation in higher education, Shabazz suggest historians might be reluctant to write about the topic because: (1) higher desegregation is still in process; and (2) historians may also be reluctant to blemish the reputations of key actors who are still living or institutions in which they work. Also see Dwonna Naomi Goldstone, Integrating the 40 Acres: The Fifty-year Struggle for Racial Equality at the University of Texas (Athens: University of Georgia Press, 2006); and Reginald Irwin DeWitty, "Ada Lois Sipuel and the Desegregation of Higher Education in Oklahoma: A Prelude to Brown" (University of South Florida, M.A. Thesis, 1992).

${ }^{32}$ Wallenstein, 142. See Statistical Summary of School Segregation-Desegregation in the Southern and Boarder States, 1966-1967 (Nashville: Southern Education Reporting Service, 1967).
} 
threatening black institutions at the same time they were creating new segregated institutions. They threatened to establish statewide admissions standards that would exclude nearly all blacks from FAMU without appreciably opening up the white schools, and they implied that FAMU might be closed. Legislators, the Board of Control, and Supreme Court justices thus defined "access" in a way that presented African Americans with a Hobson's choice between strengthening segregated black institutions or a dramatic reduction in opportunities for blacks if they continued to press for desegregation.

On the day following the Brown decision, Acting Governor Charlie Johns met with the cabinet. ${ }^{33}$ Arch segregationists such as the openly racist Johns - who had been president of the state senate and became Acting Governor when Governor Daniel T. McCarty died in office in fall 1953 - refused to make concessions, promoted Mississippi-style interposition, and favored coercion as the best strategy to defeat integration. Within state government, discourse was confined to determining the best way to preserve segregation. Racial liberals who advocated equality and an end to segregation in the foreseeable future were excluded from government positions. Moderates constituted the only real opposition within the state to the arch segregationists. Led by Attorney General Richard Ervin, State Superintendent of Public Instruction Thomas Bailey, and State Senator LeRoy Collins, moderates could countenance gradual integration in the distant future and favored "legal" means to avoid implementing Brown in the meantime. Thus, the moderates were "moderate segregationists" rather than advocates of integration, but they rejected the violence advocated by arch segregationists. The moderates had wide support among business people. As tourism replaced agriculture as the engine driving the economy, Florida promoters sought to create an image of a "moderate" state to distinguish it from other warm weather southern states where race relations remained more volatile. ${ }^{34}$ The cabinet decided that the state should respond to Brown by having Attorney General Ervin prepare a brief for the Supreme Court hearing on implementation of its order, a victory for the moderates. ${ }^{35}$ Collins defeated Johns in a special election in the fall and took office January 4,

${ }^{33}$ Tomberlin, "Negro and Florida's System," 48. The executive branch in Florida in the 1950s consisted of the Secretary of State, Attorney General, Comptroller, Treasurer, Superintendent of Public Instruction, and Commissioner of Agriculture, each independently elected.

${ }^{34}$ Arthur O. White, Florida's Crisis in Public Education: Changing Patterns of Leadership (Gainesville: University Presses of Florida, 1975).

${ }^{35}$ Ibid., 49. 
1955. By the time Ervin presented his brief in April, the moderate segregationists were firmly in control of Florida's racial policy.

Along with attorneys representing five other southern statesArkansas, Maryland, North Carolina, Oklahoma, and Texas-Ervin presented briefs to the Supreme Court. Ervin's "extensive and spirited" brief reveals that the state was using a similar rationale to deny Hawkins's admission to law school and to evade Brown. ${ }^{36}$ Rather than denouncing Brown, Ervin argued that immediate desegregation would result in violence. To bolster his argument, Ervin reported findings of a state funded study on attitudes toward desegregation, showing, he claimed, that most Floridians including law enforcement officers would actively resist any efforts to desegregate public education. ${ }^{37}$ Citing the findings of the state survey, Ervin called for a gradual process of desegregation without any deadlines. ${ }^{38}$

In Brown II, the Supreme Court refrained from setting any deadlines for desegregation. The Brown II ruling gave responsibility for desegregating public schools to local districts, not the states. The court remanded the segregation cases to federal district court justices, who "because of their proximity to local conditions" could "best perform this judicial appraisal." 39 Segregationist legislators believed that the court's decree in Brown II did not pose an "immediate threat to the tradition of segregated schools." Representative Prentice Pruitt of Jefferson County summarized the language of the decree as requiring that desegregation should occur "as soon as feasible" and stated, "It may be feasible in Florida in the next 50 or 100 years. No one would say it's feasible now." 40

The Florida Board of Control and legislators believed Brown II reinforced their argument for refusing Hawkins's admission despite the U.S. Supreme Court's ruling that Brown would prevail in higher education cases. Using the same strategy presented by Ervin, they cited existing local attitudes and the need for further study as reasons to delay. The Florida Supreme Court agreed. Citing Brown II, the Florida court ruled that although the UF could not refuse Hawkins's admission because of his race, the Board of Control could do so on the grounds that his presence would cause campus disruption. To decide when might be a feasible time to admit Hawkins, the Court appointed

${ }^{36}$ Kluger, Simple fustice, 724.

${ }^{37}$ White, Florida's Crisis in Public Education, 50.

${ }^{38}$ Tomberlin, "Negro and Florida's System," 75.

${ }^{39}$ Kluger, Simple fustice, 744.

${ }^{40}$ Herbert Cameron, "Florida Officials Express General Relief on Terms of Desegregation Ruling," Tampa Morning Tribune, 1 June 1955. 
Circuit Judge John Murphree to "gather testimony from Hawkins, the Board of Control, and other interested parties." 41

Though not unanimous, the 1955 Florida Supreme Court's decision in Hawkins reflected white segregationists' outrage with the Brown ruling. The concurring opinion of Justice William Glenn Terrell spoke loudly to what civil rights leaders were up against in Florida and the convoluted logic that would make desegregation a threat to FAMU. After discussing the problems and costs associated with moving from a segregated to a non-segregated system, Terrell asked rhetorically what the U.S. Supreme Court's mandate of "equitable principles characterized by practicable flexibility" may mean for Florida State University and FAMU: "does desegregation mean that attendance at these institutions is to be scrambled and one of them abandoned and the other enlarged at great expense in order that whites and Negroes may attend the new school? A negative answer to this question would appear to be evident." 42 Then Justice Terrell continued:

... and when God created man, he allotted each race to his own continent
according to color, Europe to the white man, Asia to the yellow man, Africa
to the black man, and America to the red man, but we are now advised that
God's plan was in error and must be reversed despite the fact that gregar-
iousness has been the law of the various species of the animal kingdom.

Although the moderates who had taken control of the executive branch rejected Terrell's suggestion that desegregation went against "God's plan," this belief was typical of southern segregationists. While this belief led Terrell to reject a plan to "scramble" white and black students by closing FAMU, he hinted at the potential threat desegregation held for HBCUs.

Floridians would understand the hint to black institutions because they had witnessed other states respond to desegregation in this way. For instance, when the University of Louisville opened its doors to African American applicants at the graduate and undergraduate levels in 1950 and 1951, respectively, the Board of Trustees closed Louisville Municipal College for Negroes. However, only fifty-five of the 146 African American students eligible for the Louisville Municipal College enrolled at the University of Louisville. There was a 70 percent decline in African American high school graduates continuing on to college in the subsequent year. Furthermore, all but one of the African American

${ }^{41}$ Tomberlin, "Florida and the School Desegregation Issue," 464.

${ }^{42}$ State of Florida, ex rel. Virgil D. Hawkins v Board of Control, 83 So. 2d 20; Oct. 19, 1955; Fla. Lexis 4002.

${ }^{43}$ Ibid., also cited in Motley, Equal fustice Under the Law. 
faculty members at the Municipal College lost their jobs. ${ }^{44}$ As historian Jean Preer argues, the higher education cases revealed a "paradox"; namely, "efforts to further legal equality might threaten educational opportunities for Black students and Black colleges." ${ }^{45}$

In addition to Murphree's court-ordered inquiry, Florida's Board of Control compiled a study based on a survey of parents, faculty, students, and alumni associated with the three state universities. The study also surveyed the facilities of the three institutions. Survey results indicated a variety of problems that could result from desegregation; however, they also revealed that only a minority of white Floridians strongly opposed desegregation, implying that moderates like Ervin exaggerated the potential for a disruptive response from whites. For instance, of the white students surveyed at UF and FSU, only 21 percent believed African Americans should not be admitted "under any circumstances," and only 1.6 and 14.9 percent, respectively, said they would drop out or transfer to a segregated college if African Americans were admitted. ${ }^{46}$ White parents and alumni were more opposed to desegregation, with 35 percent of parents indicating they would transfer their child to another institution if FSU or UF desegregated, and 33 percent of alumni stating they would stop supporting their alma mater if it desegregated. ${ }^{47}$ White parents of high school seniors expressed the most negative attitudes toward desegregation. FAMU students expressed highly positive attitudes toward desegregation with 96 percent indicating that they would not object to non-African Americans attending the university. ${ }^{48}$ In addition, nearly 90 percent of parents of FAMU students did not object to white students attending their children's school. And, finally 92 percent of FAMU alumni indicated they would continue to support their

\footnotetext{
${ }^{44}$ Motley, 97.

${ }^{45}$ For instance, the UNC case fell apart when the president of the plaintiff's historically Black alma mater refused to supply a letter of recommendation or transcript as proof of the scholastic achievement necessary to enter UNC's School of Pharmacy. Dr. James Shepard, president of North Carolina Colleges of Negroes, understood that his institution's as well as his own status depended on the very state legislators who opposed integration. Jean L. Preer, Lawyers v. Educators: Black Colleges and Desegregation in Public Higher Education (Westport, CT: Greenwood Press, 1982). In fact, Bell argues the civil rights movement contributed to the devaluation of these institutions in the higher education litigation; see Derrick Bell, "Brown and the Interest-Convergence Dilemma," in Shades of Brown: New Perspectives on School Desegregation, ed. Derrick Bell (New York: Teachers College Press, 1980), pp. 90-106. For a more recent discussion of this paradox, see Albert L. Samuels, Is Separate Unequal? Black Colleges and the Challenge to Desegregation (Lawrence: University Press of Kansas, 2004).

${ }^{46}$ Study of Desegregation, Tallahassee: Board of Control for State Institutions of Higher Learning, May 1956, 4.

${ }^{47}$ Ibid., $7,11$.

${ }^{48}$ Ibid., 13.
} 
alma mater if whites enrolled. ${ }^{49}$ Judged in light of these findings, Attorney General Ervin's and the court-appointed Murphree's claims that Hawkins's admission would cause public chaos were exaggerations. ${ }^{50}$

In 1957, Florida's Supreme Court issued its final ruling against Hawkins. Writing for the majority, Chief Justice Roberts accepted Ervin's exaggerations and argued that evidence from local studies revealed that "enforced integration" would result in a great "loss of revenue to our white state institutions." Roberts reasoned this financial cost would result from the withdrawal of white students and financial support from grants and alumni groups. In addition, he stated, "Integration would unquestionably result in the abandonment of substantially all of the graduate work" at FAMU because it would be an "unnecessary duplication" of programs at FSU and UF. ${ }^{51}$ Roberts did not seem to consider the possibility that graduate programs could have been eliminated from the other institutions or shared.

Following this ruling, Hawkins returned to the U.S. Supreme Court. Refusing to review the case, the Court recommended the petitioner "seek relief" in "an appropriate United States District Court." 52 Constance Motley explained the Court's decision:

The Supreme Court did this because it had no apparatus for enforcing its own decision, which is why an oath to uphold the Constitution is required by every state official. Under the Constitutions, the President of the United States has the responsibility to enforce the law, which includes Supreme Court decisions. Obviously hoping to avoid a federal-state crisis in 1957 in a state with a large segment of its population unopposed to integration at the university level, the Supreme Court suggested we (LDF) bring the suit in a federal district court over which it had supervisory jurisdiction, thus avoiding a constitutional crisis over state resistance. ${ }^{53}$

Given that a month earlier President Eisenhower had ordered federal troops to escort nine school children into Central High School in Little Rock, Arkansas, Motley assumed that the Court wanted to avoid another direct conflict with a state government.

\footnotetext{
${ }^{49}$ Ibid., 16.
}

${ }^{50}$ Samuel Selkow, "Hawkins, The United States Supreme Court and Justice," The Fournal of Negro Education 31 (1962): 97-101. For similar exaggerations by moderates in North Carolina, see William Chafe, Civilities and Civil Rights: North Carolina and the Black Struggle for Equality (New York: Oxford University Press, 1980).

${ }_{51}$ Hawkins v. Board of Control, 93 So. 2 d 354; 1957 Fla. Lexis 3732.

${ }^{52}$ Florida Ex rel. Hawkins v Board of Control, 355 U.S. 839; 78 S. Ct. 20; 2 L. Ed. 2d 49; 1957 U.S. Lexis 482.

${ }^{53}$ Motley, 116. 
The Florida Supreme Court's defiance in the Hawkins case showed the limits of the power of the United States Supreme Court. ${ }^{54}$ Following the U.S. Supreme Court's recommendation, LDF filed on behalf of Hawkins and other African Americans in a federal district court. However, Florida native and district court judge Dozier DeVane was a staunch segregationist. Motley notes that Judge DeVane initially "refused to hear the case, which we were now bringing as a class action." Motley recalls appearing before DeVane:

He ruled that he would set the case down for trial at a later time. He then proceeded to lecture me on all he done to help "your people in Florida." He said, "I was on the committee that set up Florida A\&M for your people. What are we going to do with that college?"55

Here again, a Florida judge suggested desegregation could result in the demise of FAMU. Ultimately, Motley secured an order from the Fifth Circuit Court of Appeals to force DeVane to hear the case.

DeVane issued an order that recognized the right of qualified African Americans to attend the University, but ignoring earlier rulings to the contrary, he refused Hawkins's admission on the grounds that he was not qualified, because his score on the Law School Admission Test (LSAT) was lower than UF's recently implemented requirement. ${ }^{56}$ In 1949, when Hawkins originally applied for admission, the Board of Control did not require LSAT scores. In 1956, Hawkins took the test, scoring $200 .^{57} \mathrm{On}$ May 16, 1958, the Board of Control adopted a minimum score of 250 for any applicant taking the test before 1958 and a minimum score of 350 for any future applicant. Hawkins agreed to withdraw his application on the condition that other qualified African Americans would be admitted to UF. According to Motley, both the state and LDF "consciously overlooked" the legal problems with DeVane's "bizarre ruling" to admit other African American students but not the plaintiff so that a deal could be worked out. ${ }^{58}$ In 1958, when George H. Starke qualified and was admitted to the UF's Law School, no public disruption ensued. ${ }^{59}$

Hawkins exemplifies how Florida officials threatened to withhold educational opportunities if African Americans sought access to white institutions. As R. Scott Barker has documented, adopting seemingly

${ }^{54}$ Algia R. Cooper, "Brown v. Board of Education and Virgil Darnell Hawkins: Twenty-Eight Years and Six Petitions to Justice," Fournal of Negro History 64 (1979): $1-20$.

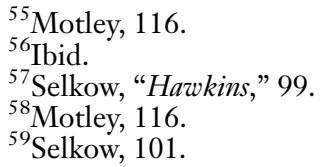


race neutral criteria for admissions such as standardized tests was used to thwart African Americans' educational advancement. ${ }^{60}$ Before using this technique to deny Hawkins entrance to law school, the Board of Control sought to use admission standards to deny blacks admission to undergraduate programs. Partly as a strategy to address increasing demand for higher education, in March of 1956, the Florida Board of Control developed proposed standards and procedures to make university admissions more selective. However, it proposed two options - one if segregation continued, another with more stringent criteria if it did not. The Board approved criteria in which a student could be admitted to a university if their scores on Florida's Twelfth Grade Test "place them above the scores attained by the lowest eight percent of freshmen admitted in September 1955, to the university at which admission is sought." ${ }^{61}$ However, the Board of Control recommended that "if integration is required," the State Board of Education should set a single standard for admissions to all three universities. According to the "Study on Desegregation," the Board of Control recommended that seniors be required to score above the fiftieth percentile on Florida State twelve Grade tests to be eligible for admission. The staff of the Board of Control speculated that if the Office of Education follows this recommendation, only 5.6 percent of African American high school seniors would be "eligible to matriculate at any State university, including Florida A and M University." ${ }^{62}$ In fact, they predicted that only 250 African American seniors would be eligible to attend a university, a sharp decline from the 800 students who had been enrolled to FAMU the previous year.

Led by Governor Collins, Attorney General Ervin, and State Superintendent of Public Instruction Thomas Bailey, moderate segregationists advocated what could be called a "carrot and stick" approach, on the one hand offering African Americans increased opportunities within segregation if they would moderate their demand for immediate integration, and on the other hand threatening black institutions if they persisted. One of the "carrots" was the development of black junior colleges to increase postsecondary education opportunities. The biggest "stick," however, was the threat to close black institutions, particularly FAMU, without affording significant opportunity at the white universities. As suggested in Ervin's Brown II brief, smaller "sticks" included reducing scholarships for

${ }^{60} \mathrm{R}$. Scott Baker, Paradoxes of Desegregation: African American Struggles for Educational Equity in Charleston, South Carolina, 1926-1972 (Columbia: University of South Carolina Press, 2006).

${ }^{61}$ Study of Desegregation, Appendix D, 1.

${ }^{62}$ Ibid., 28. 
African Americans or eliminating duplicative programs at FAMU. Throughout the early 1960s, this strategy guided moderate segregationists' response to African Americans' demand for higher education desegregation.

Governor Collins had become a supporter of junior colleges while serving in the Senate. In 1947, the year Higher Education for American Democracy was published, Governor Millard F. Caldwell appointed a citizens commission to recommend ways the state could respond to explosive growth in college enrollment anticipated over the next several decades for both whites and blacks. UF graduate student James Wattenbarger recommended establishing publicly funded junior colleges, a number for whites and a few for blacks. Wattenbarger had been hired by the commission, and Senator Collins included Wattenbarger's recommendation in the Florida Minimum Foundation Law passed that year, ostensibly to equalize funding across public school districts. $^{63}$

Despite the new law, public interest in two-year colleges was limited. During the first eight years after its passage, one existing public college and two formerly private colleges took advantage of this new source of state funding, and only two new colleges were established. The two new colleges were both in Pensacola, where whites had successfully lobbied for a school in 1948 and blacks campaigned to get their own school the following year. Washington Junior College, the black school, was located in a segregated high school. After these, no new community colleges were created in Florida until 1957.

After establishing a junior college in Pensacola, blacks did not press for additional segregated junior colleges. Some communities accepted them quietly; others protested the creation of yet another segregated system. Individual black students tried to desegregate white colleges. In the fall of 1954, inspired by the Brown decision, two young men who were co-valedictorians of Gibbs High School for African Americans attempted to enroll in St. Petersburg Junior College (SPJC). Their applications were rejected. Bailey and Ervin argued that the U.S. Supreme Court had not issued an implementation decree and the

\footnotetext{
${ }^{63}$ Governor's Citizens' Committee on Education, Education and the Future of Florida: A Report of the Comprehensive Study of Education in Florida (Tallahassee, 1947) http://fulltext10.fcla.edu/cgi/t/text/text-idx?c=fhp\&idno=CF00001663\&format=pdf; Wattenbarger, State Plan; Wattenbarger, The Community funior College in Florida's Future: The Report to the State Board of Education by the Community College Council 1957 (Tallahassee, FL: Florida State Department of Education, 1957). On the Minimum Foundation Law, see Sherman Dorn and Deanna Michael, "Education Finance Reform in Florida," in Education Reform in Florida: Diversity and Equity in Public Policy, ed. Kathryn Borman \& Sherman Dorn (Albany: State University of New York Press, 2007), pp. 53-82.
} 
Florida Constitution required segregation. The school board's attorney cited a New Jersey black newspaper editor who cautioned that "forced integration" would result in the dismissal of public school teachers. This argument shows how moderate segregationists used threats, as it was not clear why desegregating a white junior college would lead to this consequence. The following year, when a young woman who had been valedictorian at Gibbs applied for admission to SPJC, her application was rejected. ${ }^{64}$

The year 1955 was pivotal in Florida race relations and in the development of a community college system. Three key events took place that year. The first was Collins's election. Collins, in office from 1955 to 1961, became the first governor to be re-elected under a state constitution that limited governors to one full term. Throughout his administration, he pushed the junior college agenda. Second, the presidents of the UF and Florida State University adopted a policy in line with the Governor's. When the Florida Supreme Court ruled that Virgil Hawkins be admitted to the University of Florida Law School, acting as the Inter-Institutional Council, a group that excluded the president of FAMU, the presidents of the two white universities, resolved to follow a policy of gradualism and to do everything legally possible to delay integration. ${ }^{65}$ Third, Superintendent Bailey persuaded the Board of Control to appoint Community College Council to study how community or junior colleges might be used to meet the growing demand for higher education. The council hired James Wattenbarger as its first director. Although the name and function of the council changed, Wattenbarger served as director until 1967.

With some additional information on student and community interests, Wattenbarger's 1953 dissertation, A State Plan for Public Junior Colleges, with Special Reference to Florida, became the official master plan for a statewide community college system. Wattenbarger acknowledged his debt to the Truman Commission and said many years later that Florida had gone further than any other state in implementing its vision. Other than calling for a dual system, the inspiration is apparent. Like those proposed by the commission and national organization such as the American Association of Junior Colleges, the colleges he proposed would provide transfer and vocational programs but would emphasize the latter, even though Wattenbarger's own surveys showed that

\footnotetext{
36.

${ }^{64}$ Arthur O. White, "The Desegregation of Florida's Public Junior Colleges," 31-

${ }^{65}$ Minutes, Inter-Institutional Committee, Sunday, 30 October 1955, pp. 2 f., RG 440 S728, Box 1, Board of Regents, Council of Presidents Documents, Florida State Archives.
} 
students in Florida like their national counterparts clearly wanted four-year degrees. ${ }^{66}$

Once Wattenbarger's plan became official policy in 1957, community college building began in earnest. By 1962, there were twelve junior colleges for African Americans and seventeen for white Americans. In Dade County, African Americans protested the creation of a segregated college. The local school board compromised by establishing a black campus as a branch of a white college. While the white colleges had their own facilities, nearly all of the black schools were located in a segregated high school. A year after Collins left office, the establishing of black colleges ended. As Collins's successor, C. Farris Bryant was more openly segregationist and ran on a platform of reducing taxes.

Under increasing pressure to desegregate the white universities, moderate segregationists ignored blacks' court victories requiring the end of the separate but equal principle and began to make separate education more equal, at least superficially. The steps they took in that direction were modest. The black colleges had vastly inferior facilities and very limited programs compared with the white colleges. Some of the schools were likely too small to offer fully developed programs. Roosevelt Junior College in Palm Beach had seventy-three students, and Collier-Blocker Junior College in Palatka had only sixty-one. While the white colleges offered a range of technical programs, according to one study, the black schools had "limited terminal programs which tend to perpetuate job placements in low level positions and which offer no opportunities for Negro youth to break into the newly opened fields of technology." ${ }^{67}$ Thus, the new colleges were certainly separate from the white colleges, but they were far from equal.

The problem was not simply that the South was moving too slowly to dismantle Jim Crow, as though it were simply a matter of overcoming friction to get things rolling. Rather, as the Florida case shows, the real problem was that state leaders actively worked to preserve segregation and consciously defied U.S. Supreme Court orders to end segregation. The state's response in Hawkins was not the only act of defiance. The creation of a segregated junior college system from scratch flew in the face of Brown. Even the moderate segregationists' rationale that they could evade Brown "legally" must be seen as defiance; they were flouting

\footnotetext{
${ }^{66}$ Governor's Citizens' Committee on Education, Education and the Future of Florida: A Report of the Comprehensive Study of Education in Florida (Tallahassee, 1947) http://fulltext10.fcla.edu/cgi/t/text/text-idx? c=fhp\&idno=CF00001663\&format=pdf; James L. Wattenbarger, A State Plan; and Wattenbarger, The Community Funior College.

${ }^{67}$ Carroll L. Miller, "The Negro Publicly-Supported Junior College," The fournal of Negro Education 31 (1962): 386-395.
} 
what had become the "supreme law of the Land." 68 The state also opened a new university for whites only in 1960, the University of South Florida. Delay and defiance called for new tools to get real movement on desegregation. The Civil Rights Act of 1964 included levers meant to move the rock of segregation. Most telling, Title VI of the act included authority to withhold federal funds from states that did not desegregate.

\section{Florida's Response to the 1964 Civil Rights Act: Threatening the Future of black Institutions}

African Americans used the Civil Rights Act (CRA) to ratchet up the pressure to desegregate higher education. Florida whites responded by attacking black institutions. The Board of Control, local school boards, and the state department of education concocted arguments that the CRA required the desegregation or closure of black institutions. ${ }^{69}$ State University System Chancellor Broward J. Culpepper announced that unless the state acted quickly to desegregate FAMU Hospital, the State University System could lose \$30 million in federal funding, quite an astonishing claim as the federal government had not begun the lengthy administrative procedures required by the CRA before funds could be withheld. ${ }^{70}$ Florida officials who had argued for decades that separate was in fact equal suddenly discovered irreparable dilapidation and irredeemable inferiority in black facilities. ${ }^{71}$ Their solution was not to fix those facilities but to close them. Within four years, they closed all of the black junior colleges, the FAMU hospital, and the FAMU law school, claiming that desegregation required the elimination of the separate facilities. Blacks' argument that desegregation did not require the loss of black institutions had little effect, and in the end blacks had fewer educational-and health care-opportunities. ${ }^{72}$ The precipitous closing of the junior colleges following passage of the CRA shows that the moderate segregationists' claim to need time to plan a smooth transition to a unitary system and avoid disruption was merely a ploy. By the end of 1967, the state and local school districts that had governing authority over the two-year colleges closed all of the black junior

${ }^{68}$ U.S. Constitution, Article VI.

${ }^{69}$ Rabby, The Pain and the Promise: The Struggle for Civil Rights in Tallahassee (Athens: The University of Georgia Press, 1999), 187 f.; Walter L. Smith, The Magnificent Twelve: Florida's Black funior Colleges (Winter Park, FL: Four G Publishers, 1994).

${ }^{70}$ Rabby, The Pain and the Promise, 187. Culpepper served as director of the Board of Control during the 1950s and early 1960s, overseeing its activities in the Hawkins case and developing the policy of gradualism adopted by the President's Council in 1955.

${ }^{71}$ Ibid.

${ }^{72}$ Ibid., for discussion of the closure of FAMU Hospital. 
colleges and merged them with nearby white community colleges. African Americans bore the brunt of the mergers. Although enrollment in some of the black junior colleges had been declining since 1961, the mergers sent enrollments plummeting. Although open enrollment policies are typical of community colleges, Florida's white colleges adopted entrance tests and set cutoff scores "just high enough to eliminate the vast majority of nonwhite students." ${ }^{73}$ In five districts where there had been 2,000 black students in 1964, there were only 500 in 1968. Many black administrators and faculty also lost their jobs in this form of "desegregation." However, a few districts avoided these problems. Polk and Miami-Dade Junior Colleges increased black enrollment after desegregating, and in Volusia County, community members who had opposed the creation of a segregated college protested to keep it open to ensure the faculty and administrators did not lose their jobs. Their protest forced the white college to hire the president, though in a lower position, and assist faculty in finding jobs. But for most, the closing of black institutions meant the loss of jobs, weakened black leadership, and decreasing numbers of black students served. ${ }^{74}$ Had white state officials been planning how to desegregate in a serious fashion, they could have expanded blacks' opportunities immediately, as careful planning in Polk and Miami did. Instead, those white officials spent their time planning how to avoid desegregation. Faced with mounting pressure, they chose to "desegregate" in ways that undercut blacks' opportunities and disrupted their educational plans.

Florida officials did not follow the desegregation of the two-year colleges with immediate desegregation of four-year universities. Instead, resistance to desegregation depended on the prestige of the institution. African Americans had more success gaining admission to the University of South Florida (USF) than to UF or Florida State. While the latter two schools traced their roots to the nineteenth century, USF was established in 1956 and opened to students in 1960. The new university did not have a tradition rooted in segregation, did not have time to build up strong relationships with legislators, and lacked a network of white alumni. Consequently, it was more open to black students than the older, more prestigious, and more politically potent universities, though this fact did not mean that black students were treated well after being admitted to USF. Although UF admitted a black student to law school in 1958, it did not graduate an African American

${ }^{73}$ Ansley A. Abrahams and Gertrude L. Simmons, "The Educational Outlook for Nonwhites in Florida," The Fournal of Negro Education 35 (1966): 369-380, 377.

${ }^{74}$ White, "Desegregation of Florida's Public Junior Colleges," 35. 
undergraduate until 1965, tying with the University of Alabama as the last "flagship" state university to do so. ${ }^{75}$

Florida officials made only minimal gestures to desegregate the state's white universities for many years, despite persistent legal efforts by the NAACP to increase access to them. Instead, they became preoccupied with FAMU, arguing like other white southern policy makers that compliance with desegregation orders required the integration or dismantling of black colleges and universities. For a number of years, governors, legislators, and the Board of Control and its successor Board of Regents floated proposals to close FAMU, merge it with historically white Florida State University, or reduce its status, possibly converting it to a two-year school. ${ }^{76}$ Proposals to merge FAMU with FSU persisted for a decade but were eventually dropped. For example, proposals to reduce the scope of programs like confining FAMU to undergraduate education began to surface soon after FAMU acquired its first postgraduate programs in the 1950s and have continued to surface periodically. ${ }^{77}$ Although the most damaging proposals have not been implemented, and the campus retains its university status, the law school was closed four years after passage of the 1964 Civil Rights Act.

The idea of closing the law school surfaced in the 1950s, broached by Florida Supreme Court Justice B. K. Roberts, who wrote the 1957 opinion denying Hawkins admission to UF. By 1959, the year after Hawkins withdrew his application, moderate segregationist Governor Collins came to the conclusion that segregated graduate and professional schools were illegal and wasteful. He argued that the state could save money by integrating some graduate programs. ${ }^{78}$ Arch segregationists made a show of defending the law school. North Florida Senator Wilson Carraway urged increased support to strengthen and expand the law school so "there would be no demand for integration." House Speaker Tom Beasley countered Collins's argument that integration of costly graduate programs was merely fiscally sound policy by claiming that "the people are willing to pay whatever is necessary to maintain segregation.",

In 1963, the Board of Control "discovered" an increased need for lawyers in the state and authorized public universities to submit

\footnotetext{
${ }^{75}$ Robert Bruce Slater, "The First Black Graduates of the Nation's 50 Flagship State Universities," The Fournal of Blacks in Higher Education 13 (1996): 72-85, 74.

${ }^{76} \mathrm{John}$ Egerton, The Black Public Colleges, Integration and Disintegration (Nashville: Race Relations Institute, 1971).

${ }^{77}$ Johnson and Borman, "Competing Ideals of University Governance;" Rabby, The Pain and the Promise.

${ }^{78}$ Rabby, The Pain and the Promise, 188.

${ }^{79}$ Ibid., 189.
} 
proposals to meet the demand. ${ }^{80}$ UF and FSU each submitted a proposal, but FAMU did not. Though FSU's campus is less than two miles from FAMU, it proposed to establish a new "law center" with a maximum enrollment of 1,200 students, "with planning funds available in April, 1965, and classes beginning in September, 1968." ${ }^{81}$ By the mid1960s, Carraway and other more extreme segregationists had joined the moderate segregationists. "[T] he board of control and the state's white politicians - once committed to keeping black students out of the UF at any cost - were now committed to closing down the FAMU Law School and opening a new one at Florida State University." 82 Carraway sponsored legislation in 1965 providing funds to plan a law school at FSU. As the successor of the Board of Control, the new Florida Board of Regents released the funds to FSU. The next year the regents decided FAMU would not accept any new law students.

One historian of the civil rights movement in Tallahassee called the FAMU law school "small but reputable;" however, the underfunded and understaffed program remained vulnerable to criticism throughout its existence. Critics pointed out that between 1951 and 1963, only thirtytwo students had graduated from the law school, only twenty-one of whom had passed the bar in Florida or another state. Twenty-five more students would graduate by the time the school closed. Law School Dean Thomas M.Jenkins, with the support of the black community, the Tallahassee Businessman's League - the African American counterpart to the white Chamber of Commerce - and the Inter-Civic Council, representing ministers, business people, and professionals and led by veteran civil rights activist Charles Kenzie (C. K.) Steele, mobilized broad support for the college. Defenders argued that despite the lack of money and other support from the state, the school met an essential need. Graduates had become community leaders and represented African Americans who desperately needed it. They feared that white law schools would not be hospitable to blacks and would not focus on the needs of the black community. Civil rights activist and attorney John Due argued that few blacks would be able to meet admissions criteria at UF or FSU and thus would be denied an opportunity to obtain legal education. ${ }^{83}$ Their mobilization was not sufficient to stop the white coalition's plan; the last group of students graduated in 1968, and FAMU law school closed its doors. Although the regents had promised that black faculty members would not be displaced, none was hired at FSU.

\footnotetext{
${ }^{80}$ Senate Staff Analysis and Economic Impact Statement (for CS/SB 68, FIU \& FAMU Law Schools, April 27, 2000).

${ }^{81}$ Ibid. Also see Rabby, The Pain and the Promise, 188-190.

${ }^{82}$ Rabby, The Pain and the Promise, 189.

${ }^{83}$ Ibid., 5, 183, 188-190, 264.
} 
Only two applied, and they were rejected. FSU did not hire a black law school faculty member until 1970 .

The new building for FSU's law school was Roberts Hall, named after the Florida justice who denied Hawkins admission to UF and first floated the idea of closing the FAMU law program. FSU's program grew quickly but did not enroll a large number of black students. The black community resented the closing of the FAMU school, and with good reason. The decisions made in the 1960s undoubtedly have contributed to the small number of black lawyers in Florida. By the late 1990s, only 2 percent of the state bar members were black. ${ }^{84}$ One can only imagine what difference it might have made if the Board of Regents had opted to build a new 1,200-student law center at FAMU and worked diligently to attract both black and white students.

For nearly two decades, FAMU president George W. Gore successfully maneuvered between the moderate and the arch segregationists to obtain funds for his university. While his predecessors were excluded from the Council of Presidents, representing the universities in the state, Gore participated and found ways to advance the interests of his institution. On the issue of the law school, however, he was surprisingly quiet. One historian says flatly that he "did not mount an effective campaign" to save the school, speculating that he was too preoccupied with trying to defeat the numerous merger proposals, proposals that surfaced from the late 1950s through the remainder of his presidency, to contest the law school's closing. In this hostile context, Gore was nonetheless able to expand enrollment, add new programs and the buildings to house them, and obtain accreditation through the Southern Association of Colleges and Schools. He retired the year that the law school closed.

As Gore's successor in the FAMU presidency, Benjamin L. Perry explained the significance of FAMU and the private HBCUs in Florida. The idea that these institutions should be abandoned in light of recent court rulings and compliance orders was unthinkable for African Americans: "Nowhere else in Florida can a young black find the active models of leadership that he [sic] sees in our black institutions. Nowhere else can a black youngster find the type of sympathetic understanding and support that he [sic] finds at our black institutions." ${ }^{85}$ FAMU and private HBCUs provided Black Floridians with more than an education; they provided emotional, social and academic support that was not available to them at historically white institutions. ${ }^{86}$ Thirteen thousand

\footnotetext{
${ }^{84}$ Johnson and Borman, "Competing Ideals."

${ }^{85}$ Perry, "Black Colleges," 75.

${ }^{86}$ Ibid., 69-78.
} 
students had graduated from FAMU by 1975 . To inspire more students to pursue a college degree, these institutions needed to remain "visible and vibrant." African Americans supported desegregation of educational institutions; however, they realized that desegregation of white universities would move at a snail's pace, and without HBCUs many African American students would be denied a college education. Therefore, it was necessary to maintain FAMU to ensure postsecondary educational opportunities for African Americans. ${ }^{87} \mathrm{He}$ argued that the Black colleges do more than any other institutions to inspire their graduates to serve others and to "live for ideals and goals that are bigger than ourselves." Perhaps the greatest good the Black colleges could do would come from what he called "inverse integration," by which he meant that white students would begin to attend historically Black colleges and be similarly inspired. ${ }^{88}$ Perry's vision would remain unfulfilled as would any hope that the federal government would use its expanded powers under the Civil Rights Act to bring about rapid desegregation of white universities. However, NAACP litigation spanning nearly twenty years would establish in law if not in fact a vision very similar to Perry's, one in which white universities would be desegregated and Black universities would be strengthened to serve blacks' needs and attract white students.

As the department charged with enforcing the CRA in education matters, the Department of Health Education and Welfare (HEW) did not use its new powers with any vigor to leverage change in higher education. Near the end of the Johnson administration the HEW Office of Civil Rights (OCR) requested desegregation plans from ten states found to have continued dual systems of higher education-Arkansas, Florida, Georgia, Louisiana, Maryland, Mississippi, North Carolina, Oklahoma, Pennsylvania, and Virginia. Five states responded by submitting desegregation plans; however, their plans were deemed inadequate. Florida and the remaining states "totally ignored HEW's requests." ${ }^{89}$ Richard Nixon made a concerted effort to attract white suburban voters in the South with his "Southern strategy" and adopted a

\footnotetext{
${ }^{87}$ Ibid.; Deirdre Cobb-Roberts and Barbara Shircliffe, "The Legacy of Desegregation in Florida," in Borman and Dorn.

${ }_{88}$ Perry, "Black Colleges," 76. For a discussion of how threats to FAMU continued through the 1990s and affected educational policy, see Johnson and Borman, "Competing Ideals of University Governance."

${ }^{89}$ Kenneth Adams et al. v. Elliot L. Richardson, Individually, and as Secretary of the Department of Health, Education, and Welfare, et al., 356 F. Supp. 92; 1973 U.S. Dist. Lexis 14877. Nineteen states had at one time operated dual systems, but the Adams litigation focused on ten found to be still operating such systems.
} 
policy of non-enforcement in civil rights. ${ }^{90}$ Faced with southern whites' intransigence and HEW's failure to act six years after passage of the act, the LDF filed a class action lawsuit in federal district court on behalf of Black students, citizens, and taxpayers to compel HEW and secretary Eliot Richardson to enforce the law. The goal was for HEW to threaten withholding funding from states and institutions that had not taken sufficient steps to desegregate. In Adams v. Richardson (1973), the court ordered HEW to enforce the law and require states to desegregate university systems at all levels and to strengthen HBCUs. ${ }^{91}$ Upheld on appeal, this order seemed to place the biggest lever of the Civil Rights Act under the rock of segregation.

The court victory and specific features of Adams seemed to offer hope of quick action. Unlike Brown II, which delegated responsibility for desegregation to local school districts, affording each one an opportunity to resist, Adams focused on state action. States and the centralized governing bodies that typically oversaw higher education systems were required to take action affecting the entire system, offering the possibility of leveraging change in the entire system at once. It was not to be, however, because HEW did not push on the lever. In 1977, Adams v. Califano found that Florida and five other states had "not achieved desegregation or submitted acceptable and adequate desegregation plans," yet HEW had failed to take enforcement action. Even under the pressure of litigation, Florida did not produce an acceptable plan until 1978, fourteen years after passage of the Civil Rights Act and twenty-four years after the U.S. Supreme Court determined that Brown applied to higher education and ordered Florida to admit Hawkins to UF. ${ }^{92}$

${ }^{90}$ Matthew D. Lassiter, The Silent Majority: Suburban Politics in the Sunbelt South (Princeton, NJ: Princeton University Press, 2006); John B. Williams, Race Discrimination in Public Higher Education: Interpreting Federal Civil Rights Enforcement, 1964-1996 (Westport, CT: Praeger, 1997).

${ }_{91}$ Adams v. Richardson; Adams v. Weinberger, 391 F. Supp. 269; 1975 U.S. Dist. Lexis 13359; Adams v. Califano, 430 F. Supp. 118; 1977 U.S. Dist. Lexis 16561; Adams v. Bell, 228 U.S. App. D.C. 375; 711 F.2d 161; 1983 U.S. App. Lexis 26884. The Legal Defense Fund (LDF) filed suit against each secretary of Health Education Welfare (HEW) and later Department of Education (DOE) until 1988. After the Reagan and Bush, Sr., administrations persuaded the court to dismiss Adams, Florida entered into voluntary or private agreements with DOE to continue desegregating its higher education system. For a fuller discussion of these matters, see Johnson and Cobb-Roberts, "One Florida." See also, Gail E. Thomas, ed., Black Students in Higher Education, Condition and Experiences in the 1970's (Westport, CT: Greenwood Press, 1981), 329; Steven L. Wasby, Race Relations Litigation in an Age of Complexity (Charlottesville: 1995), $39 \mathrm{ff}$.

${ }^{92}$ Larry Johnson interview with Martin Chen, staff attorney, Department of Education, Office of Civil Rights; Johnson and Cobb-Roberts, "One Florida," Carol A. Williams, The Black/White Colleges: Dismantling the Dual System of Higher Education (United States Commission of Civil Rights Clearinghouse Publication 66). 
From declining enrollments in HBCUs in the years following passage of the CRA, some scholars argue that the decline was an unintended consequence of expanding opportunities brought about by the act and efforts to enforce it in Adams. ${ }^{93}$ It is also important to keep in mind, as Florida's response to passage of the act shows, that white officials like Culpepper used the act to justify attacking Black institutions, closing them completely, as in the case of the junior colleges and FAMU law school, or diminishing them. The threatened closure of FAMU law school very likely reduced enrollments the last three years of its existence, further weakening supporters' ability to keep the school open. ${ }^{94}$ The court in Adams v. Califano tried to curtail such efforts. After quoting the first Adams case, "Black institutions currently fulfill a crucial need and will continue to play an important role in Black higher education," the court noted "the real danger that desegregation will diminish higher education opportunities for Blacks." The court established a standard that the "process of desegregation must not place a greater burden on Black institutions or Black students' opportunity to receive a quality public higher education." 95

Florida's white officials continued to resist desegregating white institutions. Three years after submitting an acceptable plan, there was still little progress in the three areas covered by the plan: (1) disestablishment of the structure of the dual system, including strengthening historically Black colleges; (2) desegregation of student enrollment at all levels, undergraduate, graduate, and professional, at "traditionally white universities;" and (3) desegregation of faculty and administrative staffs, nonacademic personnel, and governing boards. The U.S. Commission on Civil Rights found that Florida had concentrated Black enrollment in the community colleges and FAMU while making little progress desegregating the white universities. ${ }^{96}$

\section{Conclusion: The Dilemmas of Access}

Following World War II, the tremendous push for civil rights occurred during a period of higher educational expansion. The Civil Rights Movement made great gains in challenging segregation on the grounds that equality of access was necessary to achieve equality of opportunity.

${ }^{93}$ Gail Thomas and James McFarland, "Have College Desegregation Policies Threatened Black Enrollment and Black Colleges? An Empirical Analysis," Fournal of Negro Education 53, no. 4 (1984): 389-397.

${ }_{95}^{94}$ Senate Staff Analysis and Rabby, The Pain and the Promise.

${ }^{95}$ Adams v. Califano, 430 F. Supp. 118; 1977 U.S. Dist. LEXIS 16561, 7. The court did not complete the comparative construction.

${ }^{96}$ Williams, The Black/White Colleges, 6. For a more extensive discussion of these matters, see Johnson and Cobb-Roberts, "One Florida." 
Yet as in Florida, state leaders wanted to expand higher education while maintaining segregation. Confronted with pressures to open historically white universities to African Americans, state officials and higher education leaders developed a variety of strategies to maintain segregation, including resisting the desegregation of UF, instituting a segregated system of community colleges and threatening to close FAMU. Redefining access to mean a choice between strengthening historically Black institutions or the token desegregation of white ones undermined efforts to expand postsecondary opportunities for African Americans.

Despite some gains in desegregating its university system, Florida has never fulfilled the requirements of its agreements with the federal government to desegregate white universities, and the proportion of students belonging to minority groups has dropped in the historically white schools throughout the State University System since Governor Jeb Bush issued an executive order, the One Florida Initiative, banning the consideration of race and gender in university admissions. This program treats access as a matter of formal criteria such as test scores and grades and has limits admissions officers' ability to take race into account. Ironically, this initiative allows universities to consider alumni status, family wealth and capacity to contribute to the institution, as well as a number of other factors. But universities may not consider the very things that have been the basis of long-standing discrimination. The centerpiece of the initiative guarantees the top 20 percent of graduates in each high school a spot at a state university, but this provision has not increased Black enrollment as promised. The outcome has been a system in which African American students are shunted into the least prestigious postsecondary institutions, the community colleges. Under these conditions, FAMU has become increasingly important in providing opportunities for a university education. Although Florida reestablished a law school connected to FAMU, it has not fulfilled the promises made in desegregation agreements between 1978 and 2003. Increasing Blacks' educational opportunities will require increasing efforts to strengthen FAMU and to increase access to historically white universities. ${ }^{97}$

${ }^{97}$ Johnson and Cobb-Roberts, "One Florida”; Williams, The Black/White Colleges. 